\title{
New Record of Pseudodistoma arborescens Millar, 1967a (Tunicata, Ascidiacea) in the Red Sea with Some Notes on the Cytotoxic Activity of the Alkaloid Content on MCF-7 Cell Lines
}

\author{
Abdulmohsin Abdullah Al-Sofyani \\ Department of Marine Biology, King Abdulaziz University, Jeddah, Saudi Arabia
}

\begin{abstract}
The ascidian, Pseudodistomaarborescens, is reported for the first time in the Saudi Arabian water of the Red Sea. It is found to be an important component of the coral reefs at a water depth of 6-13 meter of Janabiyat Island, Doga area ( $\left.19^{\circ} 46^{\prime} 09.14^{\prime \prime} \mathrm{N}, 40^{\circ} 34^{\prime} 16.33^{\prime \prime} \mathrm{E}\right)$ in December 2014. The species is redescribed and briefly its cytotoxic activity was tested. The anti-proliferative activity of the alkaloid content of Pseudodistoma arborescens has been evaluated against the MCF-7 cell line; showed $I C_{50}$ value of $0.70 \pm 0.01 \mathrm{mg} / \mathrm{L}$.
\end{abstract}

Keywords: Ascidian; coral reefs; Pseudodistoma arborescens; new record; cytotoxicity; Red Sea.

\section{Introduction}

Ascidians or sea squirts (Phylum: Chordata, Class: Ascidiacea), are the largest and most diverse class of the subphylum Tunicata. They include nearly 3,000 accepted species recorded from marine habitats (Cameron et al., 2000; Kott, 2005; Monniot et al., 1991; Shenkar et al., 2012). All ascidians are sessile distributed from shallow coastal seas to deep waters of all world oceans (Millar, 1971, 1988; Monniot et al., 1991; Monniot, 1993, 1998; Young and Vázquez, 1997; Sanamyan and Sanamyan, 1998, 2002; Lambert, 2005; Kott, 2008a, b; Primo and Vázquez, 2007; Monniot et al., 2011). Most of ascidians are filter feeders (feed on bacteria, phytoplankton and particulate matter) using a mucous net lining inside the branchial sac (Bone et al., 2003). While some deep-water species however are carnivorous (Monniot and Monniot, 1990; Lescano et al., 2011; Tatián et al., 2011;
Mecho et al., 2014). All ascidians are hermaphrodites and they generally avoid selffertilization by developing only eggs or only sperm at any point of time (Newlon et al., 2003).

Class Ascidiacea is divided into three orders based on the structure of the adult branchial sac (Lahille, 1886): Aplousobranchia (with simple slits), Phlebobranchia (with vessels) and Stolidobranchia (with folds). In the Red Sea, 73 ascidian species belonging to 13 families were recorded (Shenkar, 2012). The majority of these Red Sea species are distributes in the Indo-Pacific, Mediterranean Sea and Atlantic Ocean (Shenkar, 2012). Only $16 \%$ of these species are endemic to the Red Sea which is considerably low compared to other regions. The percentage of endemism were: $43 \%$ in New Zealand, $45 \%$ South Africa, $44 \%$ in the Antarctic region (Primo and Vazquez 2007, 2009), and $40.9 \%$ in the 
Eastern Mediterranean (Koukouras et al., 1995). In the Red Sea, the family Styelidae are the most diversified group which is the second most diverse family of the class Ascidiacea (Shenkar and Swalla, 2011). Moreover, the genus Polycarpa, which is well known for its diversity (Monniot et al., 1991) is represented with the highest number of species. During fieldwork assessing the coral reef status in Doga area, Saudi Arabian waters of the central Red Sea, an unrecorded species of Pseudodistoma was found. The general morphological characteristic of this species were close to those of $P$. arborescens originally described from Madagascar by Millar (1967).

The marine biota is characterized by ramification of the living organisms which live in the harsh perimeter (Blunt et al., 2011). Marine invertebrates, suffering from the absence of natural defenses (e.g. spines) led to the production of defense metabolites (Grabowski and Schneider, 2007). Cancer is a dreadful disease that is the direct cause of almost $14.5 \%$ of all death cases all over the world, which is found to be increased with the aging of the population (Avendaňo and Menéndez, 2015; Al-Alwan et al., 2011). This paper records the first occurrence and redescription of $P$. arborescens from the Red Sea with some notes on its cytotoxic activity.

\section{Materials and Methods}

Specimens were collected from Janabiyat Island, Doga area, central Red Sea (19 ${ }^{\circ} 46^{\prime}$ $09.14^{\prime \prime} \mathrm{N}, 40^{\circ} 34^{\prime} 16.33^{\prime \prime} \mathrm{E}$ ) in December 29, 2014 by SCUBA diving from 6 to $13 \mathrm{~m}$ depth. The samples were submerged in fresh seawater for one hour after collection and then a small menthol crystal (ca. $2 \mathrm{mg}$ ) was placed on the specimen, and kept in a fridge $\left(4^{\circ} \mathrm{C}\right)$ for 3 to 5 hours. Subsequently, sufficient concentrated formaldehyde $(37 \%)$ was added to give an approximately $10 \%$ formalin solution as final concentration. Preserved ascidian specimen was then washed with fresh water to remove formalin before dissection. Organs were stained with Mayer's hemalum stain (Humason, 1979). Specimen was dehydrated with ethyl and butyl alcohols and then mounted on a slide using canada balsam. Specimen was then examined using brightfield and differential interference microscopes (Nikon DM 6000). Drawings and measurements were made with a camera lucida attached to the microscope and an ocular micrometer respectively.

\section{Extraction, isolation and cytotoxicity assays}

The air-dried $P$. arborescens (150 g) was extracted with $\mathrm{MeOH}$ for 24 hours $(2.5 \mathrm{~L} \mathrm{X} 3$ batches, room temperature). The extract was then concentrated in vacuo $(100 \mathrm{ml})$. After that, $\mathrm{H}_{2} \mathrm{O}(300 \mathrm{ml})$ was added, and the mixture was extracted with $\mathrm{CHCI}_{3}$. The organic layer was concentrated to dryness. The residue (2.1 g) was dissolved in $\mathrm{CHCl}_{3}$ and extracted with $10 \%$ HCI until a negative Mayer test was obtained. Removal of $\mathrm{CHCl}_{3}$ from the pooled organic fraction gave an inactive extract (1.65 $\mathrm{g})$. The acidic medium was basified with $\mathrm{NH}_{4} \mathrm{OH}$ and partitioned with $\mathrm{CHCl}_{3}$. Concentration of the pooled $\mathrm{CHCl}_{3}$ fractions gave the active extract (crude alkaloids, $0.3 \mathrm{~g}$ ). The alkaloid content was tested against MCF-7 cells. Sulforhodamine assay was performed as formerly described by Tolba et al. (2013). By using $0.25 \%$ Trypsin-EDTA, exponentially growing cells were collected and coated in 96well plates at 1000-2000 cells/well. The cells were laid bare for 48 hours to the compound under investigation, thereafter, under dark incubation for 4 hours with SRB solution, which are then dissolved in DMSO. Measurement of color intensity was done at $750 \mathrm{~nm}$. The equation \% Cell viability $=\mathrm{E}_{\max } \times$ $(1-\mathrm{M})+\mathrm{R}$ is applied to estimate the dose response model of each metabolite, where $R$ is 
the resistance fraction (unaffected portion) and $\mathrm{M}=[\mathrm{D}]^{\mathrm{m}} /\left[\mathrm{K}_{\mathrm{d}}\right]^{\mathrm{m}}+[\mathrm{D}]^{\mathrm{m}} \cdot \mathrm{K}_{\mathrm{d}}$ : compound concentration that causes a one-half depress of the maximum inhibition rate, $\mathrm{D}$ : drug concentration used, and $\mathrm{E}_{\max }=100-\mathrm{R}$.

\section{Results and Discussion}

\section{Pseudodistoma arborescens Millar, 1967}

Synonyms Pseudodistoma arborescens Millar, 1967, p. 359-361, fig. 1. Gaill, 1972, p. 45, fig. 3. Monniot, F., 1987, p. 508-511, fig. 4. Monniot, C. et al., 1991, p. 1-246. Kott, 1992, p. 424.

\section{Material Examined}

Janabiyat Island, Doga $\left(19^{\circ} 46^{\prime} 09.14^{\prime \prime} \mathrm{N}, 40^{\circ}\right.$ 34' 16.33"E), central Red Sea. Saudi Arabia, 29December 2014. Depth 6-13 m.

\section{Description}

Colonies, up to 5-7.5 cm high (Figs. 1 and 2), consists of numerous lobes fused together at their lower ends with a diameter of $2 \mathrm{~mm}$, gradually increased to about $3.7 \mathrm{~mm}$ below the heads. Living specimen dark violet (or deeply colored blue) and pigment slowly dissolve in preserved materials. These lobes usually divided into 2 to 4 branches, each branch with one, two or three terminal heads. The head up to $10 \mathrm{~mm}$ in length and less than $10 \mathrm{~mm}$ in width. Heads are mostly soft compared to the stalks and a little bit cloudy or opaque. On these heads, there are superficial round apertures that mark the contracted zooid position (Figure 2). This superficial layer becomes damaged in time after preservation. Zooids are long and narrow divided into thorax, abdomen and post-abdomen with lengths ranged between 0.7-1 $\mathrm{mm}, 1-2 \mathrm{~mm}$ and 4-6 $\mathrm{mm}$ respectively (Figure 3A). The atrial siphon located short distance behind the oral siphon. Both apertures (siphons) have six evenly rounded lobes (Figure 3 B). In contracted individuals, the oral tentacles could not be clearly observed and their number was not possible to determine. Seven to 10 narrow longitudinal muscular bands are along each side of the thorax, and condense into a diffuse band that turns along each side of the abdomen to its posterior end (Fig. $3 \mathrm{~B}$ ). There are three rows of branchial stigmata, each with about 11-13stigmata. In less contracted zooids the oesophagus is moderately long and narrow leads to a small ovoid, smooth-walled stomach. The wall of stomach is indistinctly divided into four shallow folds. A short duodenal region opens into a roundish posterior stomach in the pole of the gut loop. The lower end of the ascending intestine has two small pouches. Gonads are restricted to the posterior half of the post-abdomen (Fig. 3 C). The ovary of zooids in the female phase is anterior to the position of the testis of zooids in the male phase. Ovary is represented by a compact group of oocytes. Testis consists of a longitudinal series of globular mass of follicles arranged in two rows along the posterior abdomen. The long straight sperm duct passes forward to the base of the thorax (Fig. $3 \mathrm{C}$ ). Embryo were in various developmental stages and are located in the anterior part of the oviduct within the abdomen. The larval trunk is 0.6-0.8 long, and has a rudimentary siphon, branchial sac with three rows of stigmata, sensory vesicle containing ocellus and otolith and rudimentary duct (Fig. 3 D). The genus Pseudodistoma Michaelsen, 1924 is represented by two species previously located in the family Polyclinidae Milne Edwards, 1842 (in the subfamily Euherdmaniinae) as defined by Kott (1992). The genus Pseudodistoma Michaelsen, 1924, Citoclinum Monniot, F. and Millar, 1988 and Anadistoma Kott, 1992 represent those species in which the zooids open separately to the surface of the colony and zooids have three rows of stigmata. 
The genus Pseudodistoma Michaelsen, 1924 is represented by two species previously located in the family Polyclinidae Milne Edwards, 1842 (in the subfamily Euherdmaniinae) as defined by Kott (1992). The genus Pseudodistoma Michaelsen, 1924, Citoclinum Monniot, F. and Millar, 1988 and Anadistoma Kott, 1992 represent those species in which the zooids open separately to the surface of the colony and zooids have three rows of stigmata.
The genus Citoclinum is represented by a single species C. laboutei Monniot, F. and Millar 1998 from New Caledonia. The genus Anadistomais represented by a single species A. attenuatum, Kott, 1992 from Australia (Kott, 1992). The zooids of the species in the genus Pseudodistoma are very similar. The zooids have strong musculature and zooids are often contracted to such an extent that characteristics are not visible.

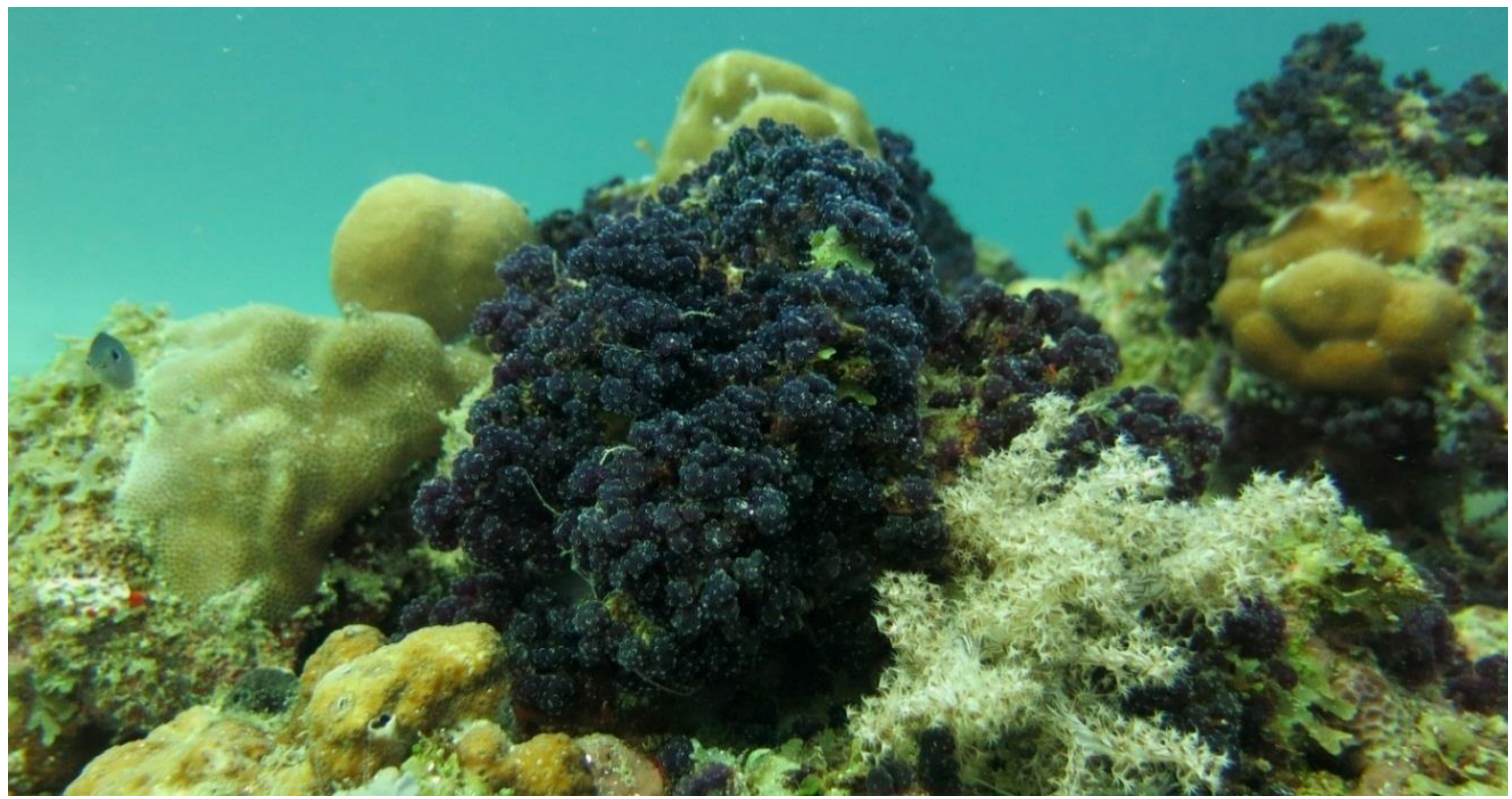

Fig. 1. Underwater photo of Pseudodistoma arborescens from the Red Sea. 


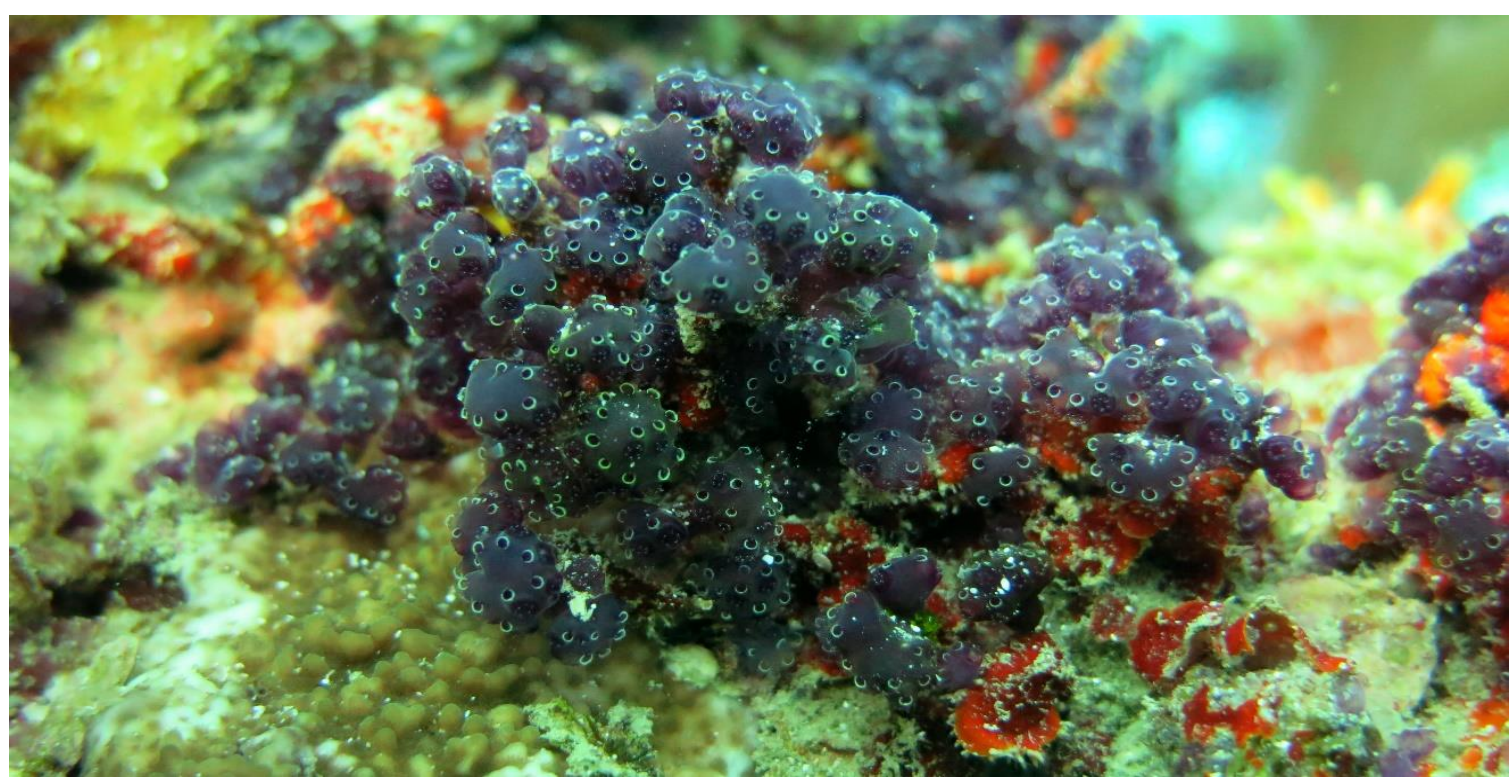

Fig. 2. Close up for the Pseudodistoma arborescens from the Red Sea. 

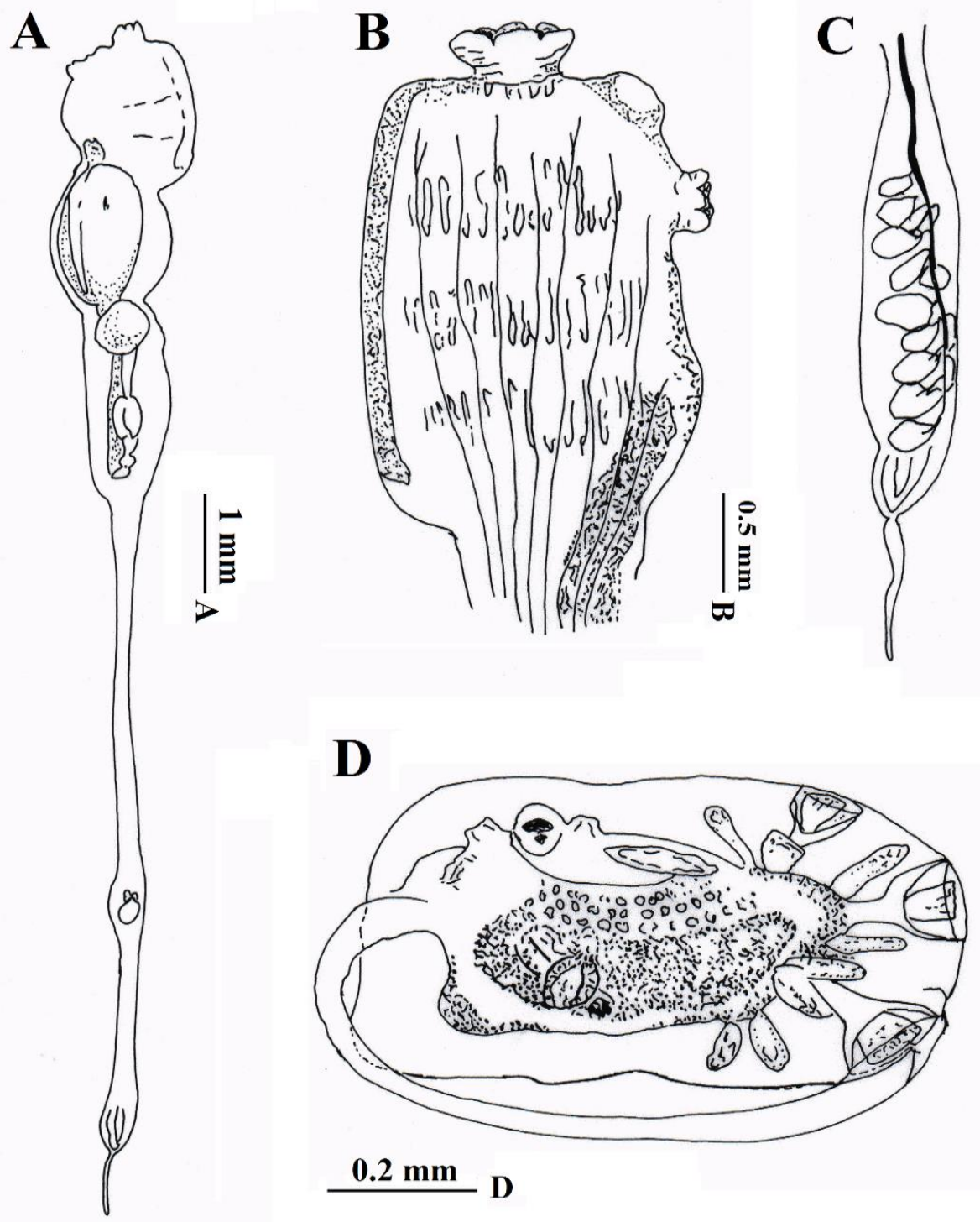

Fig. 3. Pseudodistoma arborescens from the Red Sea: a) zooid, in female phase, b) thorax, c) end of the post-abdomen of zooid male phase showing testis, d) larva for settlement.

As a result of the similarity of the zooids of the species in this genus and the contractibility of the zooids (Kott 1992) noted that the number of ampullae present in the larvae, the position of the gonads as well as the shape of the colony constitute the principle characteristics that distinguish a species in this genus. Characters generally used in the literature to distinguish between the species in the genus Pseudodistoma are compared for the thirty-one species known worldwide are: Shape of the colony, number of stigmata per half row, 
caeca, position of gonads, position embryo's are incubated, larval tail, number of larvae incubated and ampullae. The genus Pseudodistomais represented by thirty-one species worldwide. Four species have been described for the Mediterranean Sea: $P$. crucigaster, P. cyrnusense, P. obscurum and P. arnbacki (Gaill, 1972; Pérès, 1952; Pérès, 1959). A large number of species have been described for Australia and the Pacific Ocean with eleven species occurring in Australian waters, two from the Federated States of Micronesia, one from and shared by Fiji and French Polynesia, one from Papua New Guinea and the Philippines. Three species occur off the Japanese coast, and one off Korea. The Indian Ocean is well represented by the genus Pseudodistoma. A single species, $P$. arborescens, is known from the coastal waters of Madagascar (Millar, 1967), and one species, P. mauritiana, for Mauritius (Vasseur, 1967). Two species were described from the South African coast, P. africanum Millar, 1954b (Millar, 1954b, 1962; Monniot, C. et al., 2001) and P. delicatum Monniot, F., 2001 (Monniot, et al., 2001). Eight species are characterized by the absence of sand particles within the test or on the colony surface. These colonies are generally cushion-shaped, of which the surface may be produced into lobes. Colonies that have a distinctive stalk and heads may have sand particles distributed throughout the interior test, as is the case for P. africanum Millar, 1954b (Millar, 1954b) or the sand may be restricted to the basal stalk of the colony. The Pseudodistoma species with a small number of stigmata per half row are Pseudodistoma acuatum Kott, 1992, $P$. antiboja Tokioka, $1949 \mathrm{~b}$ and $P$. opacum (Brewin, 1950) which have less than ten branchial stigmata per half row while $P$. kanoko Tokioka and Nishikawa, 1975 and $P$. poculum Monniot, F. and Monniot, C. 1996 have fifteen or less stigmata per half row. Pseudodistoma arborescens, Millar, 1967, P. arnback Pérès, 1959, $P$. brieni Pérès, 1949, $P$. cyrnusense Pérès, 1952, $P$. mauritiana Vasseur, 1967 and P. obscurum Pérès, 1959 have ten to fifteen stigmata per half row. The number of ampullae present around the anteriorly located adhesive organs varies from species to species. Pseudodistoma delicatum Monniot, F. 2001 (Monniot, C. et al., 2001) described from South Africa has no ampullae present as is the case in some $P$. oriens larvae from Australia (Kott, 1992). Pseudodistoma saxicavum Gaill, 1972 has four ampullae, $P$. crucigaster Gaill, 1972 has four to six ampullae, $P$. gracilum Kott, 1992 and $P$. fragile Tokioka, 1958 has six ampullae present in the anterior part of the larvae. The remaining species, of which the larval structure is known, have eight ampullae which are generally arranged in four pairs on each side along the lateral line.

\section{Ecology and Distribution}

The percentage of coral cover was estimated using line transect method. The mean $( \pm \mathrm{SD})$ of total hard cover at 2.5 meters was $72.74 \% \pm$ $23.18 \%$ (massive $=8.97 \%$; arborescent $=$ $61.97 \%$ ). While at 7.5 meters the mean total hard coral was $18.95 \% \pm 17.95 \%$ (massive $=$ $8.57 \%$; arborescent $=9.62 \%$ ). Regarding distribution, this is species is first described from Madagascar (Millar, 1967). Subsequently, it was recorded from New Caledonia (Monniot, F., 1987) and Philippines (Kott, 1992). This is the first record of this species in the Red Sea.

\section{Cytotoxicity Assays and Viability Analysis}

The anti-proliferative activity of the alkaloid extract has been evaluated against the MCF-7 cell line and it showed the effect with $\mathrm{IC}_{50}$ value $0.70 \pm 0.01 \mathrm{mg}$.

\section{Acknowledgements}

The author is would like to express his thanks to Prof. Françoise Monniot for his help during identification process of the species. Two anonymous referees are kindly thanked for critically reading the manuscript and providing 
constructive remarks. Many thanks also to Mr. Jaafar Baomar for helping at the sea.

\section{References}

Al-Alwan, M., Olabi, S., Ghebeh, H., Barhoush, E., Tulbah, A. and Al-Tweigeri, T. Fascin (2011) Is a Key regulator of breast cancer invasion that Aacts via the modification of metastasis-associated molecules, PLoS ONE, 6 (11): e27339.

Avendaňo, C. and Menéndez, J.C. (2015) Medicinal Chemistry of Anticancer Drugs, $2^{\text {nd }}$ Edition, Elsevier.

Blunt, J.W., Copp, B.R., Munro, M.H., Northcote, P.T. and Prinsep, M.R. (2011) Marine natural products, Nat Prod Rep, 28: 196-268.

Bone, Q., Carre, C. and Chang, P. (2003) Tunicate feeding filters, J. Mar. Biol. Assoc., UK, 83: 907-919.

Brewin, B.I. (1950) Ascidians of New Zealand Part V. Ascidians from the east coast of Great Barrier Island, Trans. R. Soc., N Z 78, (2-3): 354-362.

Cameron, C.B., Garey, J.R. and Swalla, B.J. (2000) Evolution of the Chordate body plan: new insights from phylogenetic analyses of Deuterostome phyla, Proc. Natl. Acad. Sci. USA, 97: 4469-4474.

Gaill, F. (1972) Répartition du genre Pseudodistoma (Tuniciers); description de deux espèces nouvelles, Cah. Biol. Mar., 13: 37-47.

Grabowski, K. and Schneider, G. (2007) Properties and architecture of drugs and natural products revisited, Curr. Chem. Biol., 1: 115-127.

Humason, G.L. (1979) Animal Tissue Techniques, United States of America; W.H. Freeman and Company: 1-661.

Kott, P. (2008a) Ascidiacea (Tunicata) from deep waters of the continental shelf of Western Australia, Journal of Natural History, 42: 1103-1217.

Kott, P. (2008b) Ciallusiidae (Ascidiacea, Tunicata), a monotypic family from deeper waters of the tropical IndoWest Pacific, Zootaxa, 1742: 47-52.

Kott, P. (1992) The Australian Ascidiacea Part 3, Aplousobranchia (2). Mem. Qd. Mus., 32, (2): 375-620.

Kott, P. (2005) New and little-known species of Didemnidae (Ascidiacea, Tunicata) from Australia (Part 3), J. Nat. Hist., 39: 2409-2497.

Koukouras, A., Voultsiadou-Koukoura, E., Kevrekidis, T. and Vafidis, D. (1995) Ascidian fauna of the Aegean Sea with a checklist of the Eastern Mediterranean and Black Sea species, Annales de l'Institut Oceanographique, 71: 19-34.

Lahille, F. (1886) Sur la classification des Tuniciers, $C R$ Acad. Sci. Paris., 102: 1573-1575.

Lambert, G. (2005) Ecology and natural history of the protochordates, Canadian Journal of Zoology, 83: 34-50.

Lescano, M.N., Fuentes, V.L., Sahade, R. and Tatián, M. (2011) Identification of gut contents and microscopical observations of the gut epithelium of the macrophagous ascidian Cibacapsagulosa Monniot and Monniot 1983 (Phlebobranchia, Octacnemidae), Polar Biology, 34, (1): 23-30.

Mecho, A., Aguzzi, J., Company, J.B., Canals, M., Lastras, G. and Turon, X. (2014) First in situ observations of the deep-sea carnivorous ascidian Dicopia antirrhinum Monniot C., 1972 in the Western Mediterranean Sea. Deep Sea Research Part 1: Oceanographic Research Papers, 83: 51-56.

Millar, R.H. (1971) The biology of ascidians, Advances in Marine Biology, 9: 1-100.

Millar, R.H. (1988) Deep-sea ascidians from the eastern Pacific collected during the Pacific Ocean Biological Survey Program, Journal of Natural History, 22: 14271435.

Millar, R.H. (1954b) XXI- Pseudodistoma africanum sp. nov. A new compound ascidian from South Africa, Ann. and Mag. Nat. Hist., 7, (12): 128-132.

Millar, R.H. (1962) Some ascidians from the Caribbean, Studies on the Fauna of Curacao and other Caribbean Islands, 13, (59): 61-77.

Millar, R.H. (1967) A new ascidian of the genus Pseudodistoma from Madagascar, J. Nat. Hist., 1: 359361.

Monniot, C. (1993) Tunicata: On three species of bathyal ascidians collected during the Franco-Indonesian Karubar cruise, Memoires du Museum National d'Histoire Naturelle Serie A Zoologie, 158: 355-359.

Monniot, C. (1998) Abyssal ascidians collected from the proximity of hydrothermal vents in the Pacific Ocean, Bulletin of Marine Science, 63, (3): 541-558.

Monniot, C. and Monniot, F. (1990) Relationships between deep-sea tunicate populations west and east of the Straits of Gibraltar, Progress in Oceanography, 24: 289-296.

Monniot, C., Monniot, F. and Laboute, P. (1991) Coral Reef Ascidians of New Caledonia, Paris: ORSTOM.

Monniot, F. (1987) Ascidies de Nouvelle-Calédonie III. Polyclinidae du lagon, Bulletin du Muséum National d'Histoire Naturelle, (4) 9A, (3): 499-535.

Monniot, F., Dettai, A., Eleaume, M., Cruaud, C. and Ameziane, N. (2011) Antarctic Ascidians (Tunicata) of the French-Australian survey CEAMARC in Terre Adélie, Zootaxa, 2817: 1-54.

Monniot, C., Monniot, F. and Laboute, P. (1991) Coral reef ascidians of New Caledonia, Orstom, Paris.

Monniot, C., Monniot, F., Griffiths, C. and Schleyer, M. (2001) Ascidians of South Africa, Ann. S. Afr. Mus., 108, (1): $1-141$.

Newlon, A.W.I., Yund, P.O. and Stewart-Savage, J. (2003) Phenotypic plasticity of reproductive effort in a colonial ascidian, Botryllus schlosseri, J. Exp. Zool. A., 297:180188.

Pérès, J.M. (1952) Ascidies de la rôchelittorale Corse, Rec. Trav. St. Mar. End., 6, 3544.

Pérès, J.M. (1959) Campagne de la Calypso enmerd' Alboranetdans la baieIbéro Marrocaine (1958) I. Ascidies, Ann. Inst. Océanogr., Paris, 37, (4): 295-313.

Primo, C. and Vázquez, E. (2007) Zoogeography of the Antarctic ascidian fauna in relation to the sub-Antarctic and South America, Antarctic Science, 19, (3): 321-336.

Primo, C., Vazquez, E. (2009) Antarctic ascidians: an isolated and homogeneous fauna, Polar Res., 28: 403-414. 
Sanamyan, K.E. and Sanamyan, N.P. (1998) Some deepwater ascidians from the NW Pacific (Tunicata: Ascidiacea), Zoosystematica Rossica, 7: 209-214.

Sanamyan, K.E. and Sanamyan, N.P. (2002) Deep-water ascidians from the south-western Atlantic (RV Dmitry Mendeleev, cruise 43 and Academic Kurchatov, Cruise 11), Journal of Natural History, 36, (3): 305-359.

Shenkar, N. and Swalla, B.J. (2011) Global diversity of Ascidiacea, PloS One, 6: 1-12.

Shenkar, N., Gittenberger, A., Lambert, G., Rius, Rocha R.M., Swalla, B.J. and Turon, X. (2012) World ascidiacea database. Available online at http://www.marinespecies.org /ascidiacea.

Shenkar, N. (2012) Ascidian (Chordata, Ascidiacea) diversity in the Red Sea, Mar Biodiv, 42: 459-469.

Tatián, M., Lagger, C., Demarchi, M. and Mattoni, C. (2011) Molecular phylogeny endorses the relationship between carnivorous and filter-feeding tunicates
(Tunicata, Ascidiacea), Zoologica Scripta, 40, (6): 603612 .

Tolba, F.M., Esmat, A., Al-Abd, M.A., Azab, S.S., Khalifa, E.A.E., Mosli, A.H., Abdel-Rahman, Z.S. and AbdelNaim, B.A. (2013) Caffeic acid phenethyl ester synergistically enhances docetaxel and paclitaxel cytotoxicity in prostate cancer cells, IUBMB Life, 65: 716729.

Vasseur, P. (1967) Contribution l'étude des ascidies de l'ile Maurice (Marchipel des Mascareignes, OcéanIndien), Rec. Trav. Stat. Mar. Endoume, 6: 101-139.

Young, C.M. and Vázquez, E. (1997) Agneziamonnioti and Styelagagetyleri, new deep-sea ascidians specialized for life within and below the oxygen minimum layer in the Arabian Sea, Invertebrate Biology, 116, (3): 262-276.

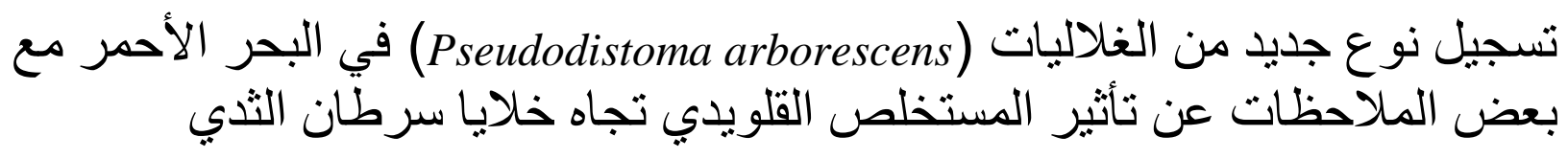

عبدالمحسن عبدالله السفياني 
قسم الأحياء البحرية، كلبة علوم البحار، جامعة الملك عبدالعزيز، جدة، المدلكة العربية السعودية

الدستخلص. من خلال هذا البحث يتم تسجيل نوع لأول مره في البحر الأحمر في المياه السعودية بمنطقة

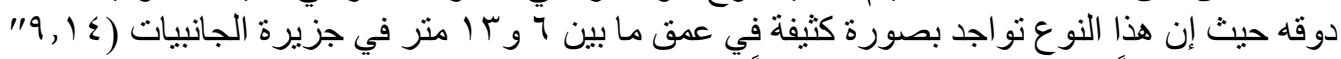

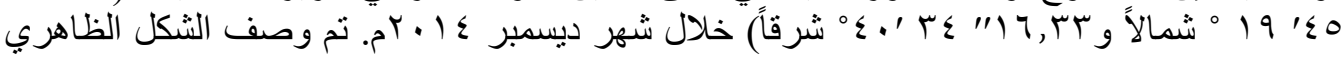



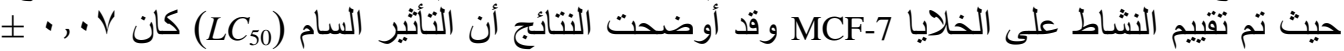

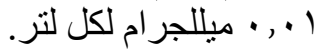

الكلمات الدالة: الغلاليات ـ الحيد المرجاني - Pseudodistom arborescens - تسجيل جديد ـ قياس السمية -

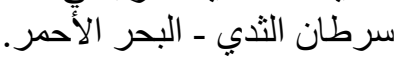

